\title{
Business Networks and Local Partners in Global Competition
}

\author{
Margherita Corniani*
}

\begin{abstract}
More and more firms address collaboration and cooperation as strategic topics in order to build up competitive networks and broaden the global competences provided by the community thus created. These firms can cooperate with partners to share resources, competences, risks or costs. Besides, penetrating new markets can be easier when associating with new partners. The process to select an adequate partner for a specific objective is a key factor of success and it varies depending on many aspects, even during the relationship itself.
\end{abstract}

Keywords: Global Competition; Networks; Partner Selection; Inside-Out Management; Outside-In Management

\section{Global Markets and Corporate Development through Business Networks}

The corporate policy of forging relationships with other companies (whether of the equity or the non-equity type), and that of developing companies 'disseminated' around the world to perform specific activities, has generated complex corporate structures, commonly described as networks (Brondoni 2008).

The development of network structures is a response to the challenges of globalisation: due to the gradual decrease in the importance of geographical, administrative, political, currency, tax, legislative, linguistic and other barriers networks have allowed companies to access broader and more open markets, with a large number of end customers but also with large numbers of companies operating at all levels of the supply chain. The scale of opportunities and threats has thus expanded enormously and companies have seen physical spaces and relationships open up, in terms of markets and companies with which to cooperate (Asmussen, Pedersen, Devinney, Tihanyi (eds.) 2011; Brondoni 2002).

Companies have been influenced to a certain extent by this phenomenon, because of the effects that the opening up of the market has generated in numerous industries, from large industries which have already been transformed by global dynamics, to smaller, more local industries that are less susceptible to the effects of globalisation. However, the opportunities to access new markets and new customers were a choice for some businesses and an obligatory step for others. The vicinity of

\footnotetext{
*Associate Professor of Management, University of Milan-Bicocca (margherita.corniani@ unimib.it)
} 
particular sources of supply or the proximity to particular outlet markets forces companies to make decisions regarding the location of branches or the development of relations with local partners in specific areas. The results of this action are often linked to the extent of a country's institutional development, rather than only to the characteristics of the businesses involved (Chan, Isobe, Makino 2008).

In global markets, the creation of business networks with different territorial, proprietary and functional characteristics, is considered decisive for the development of competitive advantage, to the point that companies often recognise that this advantage is due to the relations they have established with other companies: "We can provide additional support for the need to gain a broad understanding of resources. This includes considering suppliers as being resources of a firm, even when such resources are located outside the legal boundary of the firm" (Steinle, Schiele 2008; Dyer, Singh 1998). With the result that, at a global level, we can refer, for example, to different degrees of involvement in global sourcing relations when analysing their effect on performance (Kotabe, Murray, Mol 2008).

In fact, "purchasing is a genuinely strategic function only if it contributes to establishing a competitive advantage. The management of firm-addressable resources, especially suppliers, can be such a strategic task" (Steinle, Schiele 2008, p. 12). If relations between companies (from simple supply agreements to more complex forms of alliance) are to be justified, there must be an advantage for all the companies involved in the relationship. This must be of an economic nature (i.e. immediately exploitable such as access to supplies or to markets that are less expensive than other alternatives) or knowledge-related (i.e. able to lead to knowledge or a potential for knowledge that is higher than other alternatives, the outcome of which envisages economic benefits in the medium-long term) (Murray 2001; Christiansen, Maltz 2002; Ellegard et al. 2003). "It is widely assumed that firms establish joint ventures only when the perceived additional benefits from joint venturing outweigh expected extra costs" (Nielsen 2002; Beamish, Banks 1987; Geringer 1991).

"A firm will ally with another only if it foresees a probability of future strategically or financially benefits from the collaboration" (Overby 2005; Stuart 1998).

\section{Relations between Companies and Links within Local Areas}

"When approaching the firm-territory nexus, an important first step is to realize that firms have to be understood as part of broader industrial systems. For analytical convenience such systems are defined in functional, rather than territorial, terms, although, of course, all systems are simultaneously both functional and territorial" (Dicken, Malmberg 2001). In fact "firms in competition interpenetrate each other's territories in highly complex and contested ways" (Ibid.), which is why it is important to define where to look for partners, how to set up networks (in other words which partner to choose) and how to manage the various relationships that are established in time.

In some cases, the choice of the area in which to operate depends on the choice of the partners, which are identified by companies by the type of activity that they 
perform and by the potential competitive opportunities for the company if it establishes relationships with those specific organisations.

$\square$ Hon Hai, which is known commercially as Foxconn International Holdings Ltd, is a multinational corporation born and listed on the Taiwan Stock Exchange, with manufacturing and research centres in numerous countries around the world. It produces electronic components premises under contract for several well-known companies, including Apple, Amazon, Dell, HP, Microsoft, Motorola, Nintendo, Nokia, Samsung, Sony and others. It was founded in Taipei in 1974 to produce channel-changing knobs for black and white televisions, but then converted to connectors for computers. Starting in 1988, it established manufacturing plants in Shenzhen, China, and began to expand into various countries around the world (Czech Republic, Hungary, Mexico, Brazil, India and Vietnam, with research centres in the USA and Japan) and, thanks to competitiveness and the quality of its supplies, it became the largest Chinese exporting company and the world's largest supplier of electronic components. (Jason Dean, The Forbidden City of Terry Gou, in The Wall Street Journal, 11 Aug 2007).

On the other hand, when companies prioritise the choice of a region over that of a partner, the manner in which they activate the relationship can vary from simple supply or distribution contracts (Moore et al. 2010), to various forms of equity investments, right down to real greenfield investments, in other words, direct investments in the area of interest, establishing wholly or partially own subsidiaries (Harzing 2002). Of course, each of these solutions meets different needs, which are also linked to the peculiarities of the area in which to intervene. In fact, entering foreign markets underlines various types of problems, from the risk endemic in the country itself, to legal restrictions and market growth, all factors which, if they become extreme, may make it more prudent to enter the market by agreements with local partners rather than with wholly owned subsidiaries, in order to reduce at least some of the risks (Morschett et al. 2010).

Individual companies may have different policies related to corporate strategies rather than to specific aspects of the country they are entering.

$\square$ For example, Ferrero International S.A. is the parent company of the Ferrero Group, which comprised seventy-three consolidated companies at the end of 2013, with twenty manufacturing plants serving over one hundred end markets. Starting from the first plant in Alba (Italia), the company began its process of internationalisation back in the 1950s, establishing subsidiaries abroad by acquiring existing local firms, or by opening direct branches for all the countries selected. 
Sometimes, the need to operate in a specific area or to restock with specific components makes it necessary to develop relationships in specific territorial areas, or risk losing the related opportunities. This is true, for example, in the automotive market; when selecting suppliers, distributors or dealers in the various countries around the world; it is necessary to choose, or forego selling to specific areas.

"We provide evidence that suppliers do learn more quickly after participating in Toyota's knowledge-sharing network. Toyota's network has solved three fundamental dilemmas with regard to knowledge sharing by devising methods to (1) motivate members to participate and openly share valuable knowledge (while preventing undesirable spillovers to competitors), (2) prevent free riders, and (3) reduce the costs associated with finding and accessing different types of valuable knowledge. Toyota has done this by creating a strong network identity with rules for participation and entry into the network. Most importantly, production knowledge is viewed as the property of the network. Toyota's highly interconnected, strong tie network has established a variety of institutionalized routines that facilitate multidirectional knowledge flows among suppliers" (Dyer, Nobeoka 2000).

As it is shown by the Toyota policy, one crucial factor when selecting partners in order to develop a company's own network is therefore the prevention of advantages for the competition; in other words, by selecting those partners who might otherwise be chosen by competitors and represent competitive edge for them. In fact "the nature of relationships may matter more than the nature of resources in the networked environments" (Lavie 2006).

\section{Relations between Companies and Links between Territories}

In other cases it may be the entry country that sets the access conditions for foreign partners.

In China, for example, the entrance of foreign capital is fasttracked provided the investment is in partnership with local companies; otherwise, it may be the conditions on the potential market that suggest direct commitments abroad rather than more flexible forms of entry ( $\mathrm{Li}$, Li 2010; Minagawa et al. 2007).

$\square$ On the other hand, Chinese companies also have their own entry strategies for foreign markets, depending whether they are private or state-owned MNEs (Lin 2010).

The decision to enter foreign markets obviously reflects the need to obtain a series of results ranging from the search for new knowledge to the search for raw materials, semi-finished products and products that are not available elsewhere, or, simply, the search for processing costs that are lower than elsewhere. In this sense, 
we refer on one hand to outsourcing policies, which can naturally be put in place locally or in distant locations -offshore outsourcing- (Benito 2013; Farrell 2005), depending on the related economic convenience (Lewin 2011).

The creation of a network constitutes a means of governing the global dimension, and explains how strategic alliances effectively "shift the very basis of competition to a new level - from firm to firm to (...) rival groupings of collaborators" (Powell 1987) "which means that the performance of a firm is intimately tied to the performance of its collaborative engagements" (Overby 2005; Dyer, Nobeoka 2000). In fact, "today competition is often regarded as taking place between well run inter-firm constellations" (Deligonul et al. 2013).

In the last thirty years, the frequency with which relationships have been forged between companies on a national and a global scale has generated numerous management studies which reflect different approaches to identify the underlying motivations that have prompted companies to establish various types of relationships with other companies. For example, the development of international collaboration agreements between companies has been attributed to market globalisation and the increase in competitive dynamism this has triggered in many sectors (Harrigan 1988; Glaister, Buckley 1996). Before globalisation was introduced to stimulate the development of these relationships, alliances between companies were explained as a consequence of a number of factors, from different theoretical perspectives to corporate studies: the theory of transaction costs (Williamson 1985; Hennart 1991), that of resource dependency (Pfeffer, Nowak 1976), the theory of organisational learning (Hamel 1991; Grant 1996), the theory of strategic positioning (Porter, Fuller 1986) and institutional theory (DiMaggio, Powell 1983; Meyer, Rowan 1977). Most management researchers therefore had to examine the motivations that could induce these companies to try to establish relations with other companies, attributing specific importance to these motivations as part of defined theoretical approaches to the analysis of companies and management decisions. However, only a small number of scholars concentrated on problems that were more specific but extremely important for the running of a company, such as the method and motivation behind the choice of specific partner companies (Nielsen 2002).

The selection of the companies with which to ally is a very significant part of the creation of alliances between companies (Gulati 1995), as the success of an alliance depends on the characteristics of the partner chosen, and the sum of the skills and resources that the partner intends to invest in the relationship, in combination with the strategic objectives of the partnership itself. For this reason too, selecting a partner for an alliance is a highly significant process and constitutes a specific decision in the process of creating an alliance, which highlights the question of which is the right partner to involve (Reynolds 1979; de Hoghton 1966), although the problem of identifying the correct partner is anything but simple (Overby 2005).

Some scholars have developed this idea, identifying specific criteria that make it possible to define a partner's correctness (Glaister 1996), distinguishing in particular between criteria linked to the task to be performed (task-related criteria) and criteria regarding the partner (partner-related criteria) (Geringer 1991). The former, in particular, refer to the skills and operational expertise at the partner's disposal, which he can contribute to the partnership; the latter, on the other hand, regard the partner's own characteristics, in terms of effectiveness and efficiency. 
Others still have focused on criteria linked to the cultural (both corporate culture and national culture), strategic, organisational and financial aspects of the partners (Yan, Luo 2001). But these perspectives have highlighted the difficulties inherent in defining the partner selection criteria in advance, suggesting that "the relative importance of partner selection criteria may be determined, on a contingency basis, by the variables associated" (Geringer 1991; Reus, Ritchie 2004). In fact, contingency regards a whole variety of elements that are very important for the construction of alliances, which include the specific situation in which companies operate at a particular moment (with reference to the available skills and resources) but also elements foreign to the company and linked to the competitive context of its activities. As a result, the partner selection criteria can change even during the life cycle of an industry, prioritising aspects linked to the resources to be shared at certain times, and aspects linked to the partner's ability to relate to other parties at other times (Overby 2005).

\section{Corporate Relations and Inside-Out Management}

The selection of a partner to involve in its activities to a greater or lesser extent and for a shorter or longer period, always obliges a company to open itself up (and its information systems in particular) to the outside world, and to a third party that it cannot control. This aspect is the central critical point that underpins any decision to interact with other companies, and becomes even more important the greater the company's involvement in the partnership, i.e. the broader the heritage of information that the company must share with its partner and the higher the risk shared by the companies in the partnership (co-makership) (Brondoni 2005).

Usually, when co-makership relations are developed, the parties involved share the corporate risk and are therefore all stimulated to adopt behaviour that is instrumental to the goals of the co-makership alliance. For example, this is true for franchising agreements where the franchisor and the franchisee are, obviously, both interested in promoting the business in the same direction. It is also true for relationships that evolve between a few key suppliers and important companies, for both of which the success of their respective activities depends strictly on the smooth operation of the co-makership partnership established. However, not all partnerships are of the co-makership type and when a company has to open up to other companies, sharing information with them, this highlights the problem of the risk of opportunistic behaviour on the part of the companies involved, and it reduces companies' readiness to sustain investments dedicated to the smooth functioning of the relationship. This is quite a common situation in the context of partnerships that entail the transfer of proprietary knowledge such as the fruit of research or development, carried out for example by a supplier which, the more it fears that its clients might appropriate its R\&D knowledge, the more cautious it is to promote investment in the development of relations with specific clients (Martinez-Noya et al. 2013).

Naturally, these fears regarding the misappropriation of knowledge and the cancellation of potential advantages deriving from the partnership depend enormously on the content of the knowledge transmitted through the partnership, but also on the nature of the companies involved (Yang 2012; Li, Xie 2011). 
Numerous scholars see this primarily as a problem of relations with countries with a lower technology content, where manufacturing activities can be outsourced in order to cut costs. In this case, the characteristic dilemma is based on the alternative between granting expertise (and often the technology itself, in terms of machinery, dedicated personnel, etc.) and teaching other companies, to enable them to turn out high tech products at a lower cost, thus creating potential competitors. The alternative is to forgo this significant reduction in manufacturing costs and not to be competitive on global markets (Peng 2012; Wen, Chuang 2010; Trott, Oecht 2007).

The risk of opportunistic behaviour on the part of the companies involved in corporate networks has been the subject of extensive analysis in literature, particularly in the context of sociology studies which analyse the sociological motivations underpinning the alliances, focusing attention on the issue of trust in the development of networks between companies, and identifying them as an important factor to be taken into consideration when selecting partners to involve (Day et al. 2013; Varis, Conn 2002).

It is therefore possible to characterise the approach to partnerships according to two perspectives: the inside-out perspective and the outside-in perspective, which underline the different approaches that companies tend to adopt as part of the process of identifying and managing their relationship with other companies. From an inside-out perspective, in the context of the global markets the partner that a company looks for is one to be "exploited" for its network system, to obtain a specific competitive advantage for itself. The company is therefore looking for third parties to which it can transfer its own products or from which it can stock up without being prepared to transfer knowledge or resources, even motivated by the risks of opportunistic behaviour by the other party.

This prospective of "exploiting" short and even medium-term opportunities, is a feature of relations in which a dominant company can choose different outlet or supply alternatives, drawing on the competitive advantages of a particular market in terms of the size of the outlet market, the backwardness of the market itself, the availability of natural resources at a low cost, access to inexpensive manpower, etc.).

Where textile production is concerned, there is a very large area of the world, made up of Southeast Asia and in particular countries like Bangladesh, Pakistan, India and Sri Lanka, where the world's large textile and clothing manufacturers stock up because of the low manufacturing costs. The companies in this region are able to manufacture products at various quality levels for their clients around the world, in very high quantities, basing their competitive cost advantage on the availability of low cost manpower, and local legislation that makes it possible to cut the cost of environmental and social protection. The relationships developed between the large global textile and clothing companies and the companies located in this vast global region are not driven by formulas of sharing and openness, but rather by the need to achieve low cost, even dedicated products. The level of know-how sharing can therefore be very low, favouring an approach based on the exploitation of the supplier according to an 
inside-out perspective on the part of global companies that supply themselves there (Burki, Cadden 2011).

From an inside-out perspective, companies have specific resources inside their structure, and their competitive ability lies in combining these resources so as to achieve an edge over competitors who do not have the same resources, or do not know how to combine them in a similar way (Arrigo 2012; Sciarelli 2008). This capacity to combine resources (inside) also contemplates the possibility of "exploiting" the "opportunities" for transactions in relations with other companies, in order to put a competitive product range on the market (outside).

Clearly, from this inside-out perspective, the parties involved do not tend to invest in developing the relationship, which functions as long as the envisaged economic advantages exist for both parties, from the perspective of "exploiting" mutual advantages. Networks whose aim is to transfer confidential knowledge or to acquire it outside the company are therefore not developed, but one company will regard the other party as an opportunity to exploit.

This perspective, which is also widespread on global markets, is suitable for relationships in which there is always a stronger company which is able to dictate the conditions and to offer its counterpart opportunities for procurement or supply, without needing to share knowledge that is "significant" for its own business.

Naturally, in a similar context, identifying companies with which to develop networks presupposes specific selection criteria, which focus primarily on enhancing the opportunities to exploit, certainly in the short but also in the medium term. In a certain sense, the relationship is identified from the viewpoint of facilitating the company's output to the market: a client is chosen in order to exploit its potential market, or a supplier because the economies achieved with this relationship make it possible to market a particularly competitive output.

\section{Business Networks and Outside-in Management}

Business networks may be structured with an outside-in approach. In this case, a company looks to other companies for the resources and skills that it does not have, and forges relations of various types to take those resources and skills on board. Instead of developing these resources internally, which would be a long, expensive and often very risky process, many companies operating on global markets choose the outside-in solution. This implies identifying the resources and skills considered necessary outside the company, and activating procedures designed to "import" these resources into the company. This "importing" process does not necessarily mean acquiring resources and skills from other parties, but putting themselves in a condition to access them, reaching agreements for the management of variously structured relationships.

The input aspect of the relationship is prioritised, facilitating the entrance into the company of the resources and knowledge that pave the way for the development of the company's own competitive capabilities.

This approach naturally tends to be developed with a long-term perspective, and presupposes that the parties involved in the process of sharing the resources are prepared to share, with all the related risks. On one hand, we must therefore 
consider the problem of opening up the relevant computer systems and sharing critical information, while on the other hand there is a risk that someone who acquires new skills will transfer them to competitive third parties, or will himself be transformed into a competitor, rather than a partner. And finally, there is a generic risk of opportunistic behaviour, in which case a company that invests more than the others in the network does not obtain the expected advantages from the relationship, because of the opportunistic behaviour of the other parties.

Some analysts underline the importance of involving companies in the network because the relationship itself can bring the desired performance. This involvement regards the unlocking of the information systems involved but also the ability to dedicate specific resources and investments to the partnership that focuses on the development of outside-in management. "The strategic importance of a supplier is, in our view, determined by (a) relationship dependencies and (b) the future opportunities for relationship development" (Ivens et al. 2013). In this sense, we should mention specific operational figures who are important for the successful functioning of the relationship, such as the key supplier managers or key account managers, who manage the partnership relationship, and are recognised as key elements of the development of the corporate network (Makkonen, Olkkonen 2013).

In particular, inside-out and outside-in approaches can also be linked to the concept of value appropriation and value creation: "Value creation, on the one hand, is concerned with creating valuable benefits for customers, e.g. in the form of innovation, distribution or production (...). Value appropriation, on the other, focuses on a company's activities that aim at extracting profits from the market" (Ivens et al. 2013). In this sense, inside-out management can be associated with the logic of value appropriation. This means that the company which develops the relationship does so to appropriate the value that derives from having exploited specific resources, even when these are obtained through a network. On the other hand, outside-in management, which postulate the search outside the company for the resources and knowledge necessary for internal development, are more closely linked to the logic of value creation, by which resources acquired externally and imported into the company are identified and 'imported' for the purpose of creating value for the market and destined to affect the overall system of the players involved in the relationship.

It is clear that, from this perspective, the timeframe tends to be wider and the dynamics of the relationship that is established between the companies are more far-reaching, presupposing greater sharing of knowledge and information. This facilitates the evolution of the relationship and, therefore, the creation of the value that is determined, after having acquired the resources and knowledge that are lacking outside the company. The traditional resource-based theory maintains that the company should be stimulated by the search for the resources it is lacking, in order to generate them internally or to obtain them in some other way (for example through relationships with other companies). This approach, on the other hand, maintains that, if the company adopts an outside-in attitude, what counts in the relationship between companies are not only the resources to be acquired/shared, but also and above all the other party's determination to pool these resources and to foster their effective use. 
口 "We emphasize logistical management activities on a global basis which we call global sourcing strategy - and also the importance of retaining the company's capability and gaining access to suppliers' capabilities to design and develop major components and finished products. These capabilities allow the company to better understand the cost and quality implications of its sourcing relationship with its suppliers" (Kotabe, Murray 1994).

Partnerships therefore tend to address parties which have useful resources, rather than really unique resources, and are highly motivated to bring them into play in the relationship, not considering it useful to pursue opportunistic behaviour. In practice this means selecting partners according to so-called partner-related criteria rather than task-related criteria, where the availability of the resources is important but less so than the parties' determination to share them in the partnership (Overby 2005).

However, in the development of business networks, it always seems more opportune to adopt a perspective that moves away from an examination of the individual binary relationship forged between two companies, in favour of an analysis of the complex system of companies that are part of a network, from a broader perspective (Steinle, Shiele 2008). In fact, each company involved in a single corporate relationship is in turn part of other relationships, in other words it has its own network. As a result, in every corporate relationship, several networks come into contact with each other. However, the way in which these networks come into contact and the potential that these contacts can open up for the companies involved is very different. In this sense, there are people who study corporate relations, taking specifically into account the fact that a company can be interested in developing a clearly defined relationship with another company in order to enter the latter's network and to gain access to a wider system of opportunities and resources (Bhalla, Terjesen 2013). "The importance and effect of key supplier relationships are broader than the relationship itself" (Ivens et al. 2013) because the development of a relationship also opens up other relationships which are those that a company establishes with its own network and which it cannot and must not overlook when it chooses other companies with which to establish relations (Holmen et al. 2013).

A company's degree of involvement in a specific network makes it possible to highlight: on one hand the potential contacts that can be generated by entering a relationship with this specific company and, on the other, the company's reliability in the development of new relationships. A company's role in its own network can be identified as a deterrent to the adoption of opportunistic behaviour in relation to company networks which can, in some way, have repercussions for the network itself (Bhalla 2013).

This 'Trojan horse' perspective is very important when analysing the selection of partners with which to establish relationships, because of the broad horizon of potential that can be triggered by activating significant relationships with another company, opening up new networks and new relationships and opportunities. 
The principle of the network picture should be seen in this context, in other words, as a representation of a company's relations with its suppliers, clients and competitors. Interpreting another company's network from the viewpoint of a specific firm which establishes or intends to establish a relationship with that company is extremely significant when selecting partners and the best way of managing the relationships to be established with them.

From an outside-in perspective, the network picture is a necessary step that the company has to take in order to grasp fully the opportuneness of forging a relationship with another company. This is not only for the results that are the actual target of the relationship, but also because contact with this company grants access to another system of relationships, i.e. the other company's network which, in turn, reveals opportunities and risks that can be extremely important (Roseira et al. 2013). "Buyers must manage their key suppliers in their network contexts. (...) Instead of managing a key supplier as if it existed in isolation, a buying firm may develop a network awareness capability in order to manage the key supplier in its wider network context" (Holmen et al. 2013).

The involvement of companies in networks with other businesses is seen as a decisive factor of the success of this relationship, both for the learning process for the involved companies (outside-in): "access relationships represent opportunities for firms to create value through learning new skills and leveraging the complementary resources of their partners" (Sarkar et al. 2001; Hitt et al. 2000), and for the possibility for secondary minor opportunistic action: "given a finite number of desirable partners who possess required resources, are partnering oriented, and are less likely to act as predator or opportunistic, proactiveness allows small firms to select from among the best" (Sarkar et al. 2001), the larger the investment dedicated to making the relationship work, in other words the higher the degree of proactiveness of the parties involved: "assigning resources to alliance identification and development may create value and better performance" (Ibid.).

\section{Intensity of the Relations between Companies in a Network}

The interest of all parties in joining an alliance or a joint venture or, more generally, in relating to other companies is therefore recognised as decisive for the success of that relationship. The motivation to form an alliance and the success that this might generate can be expressed in various ways and, therefore, also measured using different benchmarks. However they all converge on the corporate results of higher sales and lower costs, in the short or long term. In this sense, the greater the interest in entering a network of relationships, the greater also the degree to which companies are prepared to involve themselves in this network, forging relationships, dedicating resources to their management and sharing the risk that derives from them.

This perspective is particularly evident in certain businesses for which intangible resources, particularly those that are knowledge-related, are essential to the definition of alliances. In this case, corporate relationships are not motivated by cost reduction targets or the need to identify more efficient manufacturing processes, etc. but stimulated by research to develop new products or processes. 
This is evident in the ICT, pharmaceutical and biotechnologies fields and, more generally, in the context of business with a high level of R\&D (Cavusgil, Evirgen 1997; Colovic 2007; Gattai, Molteni 2007).

On the other hand, a network organisation and the outside-in perspective that stimulates it underline the fact that relationships between companies cannot be considered from a binary perspective, but in relation to the fact that these are 'multi-partner' networks. Several partners are always involved, and these in turn are connected to other partners. This system of successive interwoven relationships cannot be overlooked in the development and management of individual binary relationships.

This consideration highlights the fluidity of barriers between companies which tend to become blurred and more dynamic in time and space the more relationships a company forges with other companies. In fact, the spread of corporate relationships at all levels and in all directions (purchasing, supplies, competition, etc.) induces us to shift our attention from the company to the network that it belongs to, and from the single network to the multiplicity of networks. In other words: "firms within industrial systems: firms as networks within networks" (Dicken, Malmberg 2001).

Nor can we therefore disregard the local dimension of the relationships that companies in a network establish with other companies when they set up their own network. We could describe this as geographic embeddedness in order to understand the repercussions that certain relationship choices can trigger for the entire system: "there is a growing body of evidence to suggest that the particularities of a unit's territorial embeddedness are centrally important to the nature and influence of subsidiary units within firm structures" (Dicken, Malmberg 2001).

The significance of this system of relationships is so important that for some time now, scholars have sustained the responsibility of the network; in other words, the repercussions of any action taken by other companies in a particular network for the companies involved in the same network - particularly the largest which attract the attention of the competition and the markets (Brondoni 2003). Take the example of global sourcing alliances: "Purchasing managers see themselves confronted with the board's expectation to purchase larger volumes of supplies from low wages countries. Even the set-up of global sourcing quotas has been reported, imposed by the board. However, the question arises of whether a high global sourcing quota is always best for a firm? Low prices may not automatically translate into lower total costs of ownership, if additional transport costs, maintenance costs or quality costs arise" (Steinle, Schiele 2008).

In addition to the factors of economic convenience and competitiveness that induce companies to invest resources in networks, these aspects of responsibility explain the tendency to develop focused relationships, particularly with a few crucial and not easily replaceable partners, inasmuch as the market and the competition system permit. In fact, certain partners even become co-makers because of their specific importance in a market context, which is very much the case for specific dealers in the automotive market. Their importance for the manufacturer is closely linked to the system of relationships that these operators maintain in a specific area. In practice, manufacturing companies are often faced 
with the alternative between serving a particular territory or not serving it when they choose their dealers (Bucklin et al. 2008).

The relationship that is established in these cases between the manufacturer and the local distributors (by the same is true for supply systems, for example) is a twoway relationship, with respect to the opportunities that are generated. On one hand, we have the manufacturing company that manages to sell or to stock up, often with a monopoly, in a particular region - and therefore accesses specific market potential thanks to another operator's activities. On the other, the co-maker company takes advantage of its partner's network, expertise and competitive capabilities to exploit the potential he enjoys in a specific local market (Arnold, Quelch 1998). In this sense, numerous outsourcing alliances, driven by the need to cut costs in countries where manpower is less expensive and the tax burden is less oppressive, are gradually transformed into more complex, ramified networks, based less on mere cost reduction and increasingly motivated by more competitive stimuli (for example, in the case of the selection of a supplier or a distributor, to make him unavailable to the competition). They even develop relationships that are contractually more complex: "outsourcing could be tied to a licensing arrangement with the foreign contractee" but in any case, "outsourcing can involve much more than the outsourcing act itself” (Benito et al. 2013).

Ikea, the global furniture manufacturing and retail giant develops its business thanks to numerous networks and relationships that regard the system of the manufacturing companies and those of retail distributors under franchising agreements (Hultman et al. 2012).

Where its suppliers are concerned, Ikea maintains targeted relationships that focus on the development of long-term collaboration to obtain from them investments dedicated to cost reduction and an increase in overall margins, to be shared between Ikea and its suppliers (Nohria, Eccles 1992; Elg et al. 2012).

Where the distributors are concerned, "Ikea franchisees implement the Ikea Concept by marketing and selling the Ikea product range and have the responsibility to run, manage and develop the Ikea operations locally. With the exception of the Ikea Delft store, all Ikea stores operate under franchise agreements with Inter Ikea Systems B.V. Inter Ikea Systems B.V. is constantly evaluating new countries and is following a long-term strategic expansion plan, which sets out priorities of future growth, where to put focus and when. Entry to a new country is made after thorough market studies and franchisees are carefully evaluated prior to selection".

\section{Conclusion and Emerging Issues}

Selecting partner with whom to establish long-term relationships, and to forge the stable links of a network, is a significant issue that must be tackled in full knowledge of the facts, and considering both "task-related" and "partner-related" elements to justify investments that have an impact on both the economic-financial dimension and the competitive dimension. Last but not least, they will impact on 
aspects related to intangible corporate resources (corporate culture, computer system and corporate identity) (Corniani 2010).

When selecting franchisees, Inter Ikea Systems B.V., among other things, evaluates the following:

- Experience

- Local market knowledge and presence which has to demonstrate ability to establish and operate Ikea stores nationally

- Corporate culture and values

- Financial strength and ability to carry through the investment penetrating a country in full and in a large-scale retail environment".

Selecting partners that may become co-makers or which are already identified as such, is in fact only a part of the process that leads to the establishment of the relationship which, as such, is a dynamic process. The variables guiding the partner selection process are linked both to the contingent demands of the companies involved, in relation to the competitive system in which they operate and the related network of relationships, and to a perspective vision of the potential that the relationship will generate over the years. However markets, companies and, more generally, competition systems do not always evolve in the expected direction, and therefore networks between companies will not always continue to be useful, sound and opportune. In fact, there are distinct stages even in relations between companies: training, implementation and evolution. The variables used during the partner selection stage tend to define the rules of the relationship, but the relationship is first and foremost a social process in which strictly economic factors do not always dominate, as we can see from a longitudinal analysis conducted on alliances between companies (Varis, Conn 2002).

The dynamic dimension of relations between companies therefore becomes the central aspect of the development and management of business networks. In fact, it is advisable to observe that during their individual life cycles, companies need different resources and opportunities and, even for this reason, they demand different outcomes from the network they create. Investments targeted to relationships are therefore questioned and the risk of opportunistic behaviour is very high, both for small partners who have everything to lose, and for large partners who have a great deal to lose: "this implication is important as an increasing number of alliances involve links between smaller entrepreneurial firms and larger established firms" (Overby 2005).

The dynamism of relationships between companies therefore highlights the limits of the so-called "network picture", in other words a representation of the network of its own potential or actual partners, which is also subject to variability in time. This shifts attention in the development of corporate relations to two key elements:

- the availability of a suitable system that can manage significant information about potential and actual partners, and is also able to monitor their evolution, gasping the significant signals in plenty of time;

- investment in dedicated figures to manage the networks who, rather than focusing only on finding ways of cutting costs, must be capable of identifying the potential of the relationship to generate effectiveness and efficiency in the medium 
and long term, from a more entrepreneurial perspective, and they must be able to analyse and assess the correct state of the network picture in time (Holmen et al. 2013).

\section{Bibliography}

Arnold David J., Quelch John A. (1998) New Strategies in Emerging Markets, MIT Sloan Management Review, vol. 40, n. 1, pp. 7-20.

Arrigo Elisa (2012) Alliances, Open Innovation and Outside-in Management, Symphonya. Emerging Issues in Management (symphonya.unimib.it), n. 2, pp. 53-65.

http://dx.doi.org/10.4468/2012.2.05arrigo

Asmussen Christian Geisler, Pedersen Torben, Devinney Timothy M., Tihanyi Laszlo (eds.), (2011) Dynamics of Globalization: Location-Specific Advantages or Liabilities of Foreignness?, Emerald Group Publishing Limited, Bingley.

Badaracco, Joseph I.(1991) The Knowledge Link: How Firms Compete Through Strategic Alliances, Harvard Business School Press, Boston.

Beamish Paul W., Banks John C. (1987) Equity Joint Ventures and the Theory of the Multinational Enterprise, Journal of International Business Studies, vol. 18, n. 2, pp. 1-16.

Benito Gabriel R.G., Dovgan Olesya, Petersen Bent, Welch Lawrence S. (2013) Offshore Outsourcing: A Dynamic, Operation Mode Perspective, Industrial Marketing Management, vol. 42, pp. 211-222.

http://dx.doi.org/10.1016/j.indmarman.2012.08.003

Bhalla Ajay, Terjesen Siri (2013) Cannot Make Do Without You: Outsourcing by KnowledgeIntensive New Firms in Supplier Networks, Industrial Marketing Management, vol. 42, pp. 166179.

http://dx.doi.org/10.1016/j.indmarman.2012.12.005

Brondoni Silvio M. (2008) Market-Driven Management, Competitive Space and Global Networks, Symphonya. Emerging Issues in Management (symphonya.unimib.it), n. 1, pp. 14-27.

http://dx.doi.org/10.4468/2008.1.02brondoni

Brondoni Silvio M. (2005) Managerial Economics and Global Competition, Symphonya. Emerging Issues in Management (symphonya.unimib.it), n. 1, pp. 14-38.

http://dx.doi.org/10.4468/2005.1.02brondoni

Brondoni Silvio M. (2003) Network Culture, Performance \& Corporate Responsibility, Symphonya. Emerging Issues in Management (symphonya.unimib.it), n. 1, pp. 8-24.

http://dx.doi.org/10.4468/2003.1.02brondoni

Brondoni Silvio M. (2002) Global Markets and Market-Space Competition, Symphonya. Emerging Issues in Management (symphonya.unimib.it), n. 1, pp. 28-42.

http://dx.doi.org/10.4468/2002.1.03brondoni

Bucklin Randolph E., Siddarth S., Silva-Risso Jorge (2008) Distribution Intensity and New Car Choice, Journal of Marketing Research, vol. 45, n. 4, pp. 473-487.

http://dx.doi.org/10.1509/jmkr.45.4.473

Burki Umar, Cadden Trevor (2011) Strategic Alliances and Relational Governance: Evidence from the Pakistan Textile Industry, paper presented at EUROMA, N/A.

Cavusgil Tamer S., Evirgen Cuneyt (1997) Use of Expert Systems in International Marketing: An Application for Co-operative Venture Partner Selection, European Journal of Marketing, vol. 31, n. 1, pp. 73-86.

http://dx.doi.org/10.1108/03090569710157043

Chan Christine Man Kuen, Isobe Takehiko. Makino Shige (2008) Which country matters? Institutional development and foreign affiliate performance, Strategic Management Journal, vol. 29, n. 11, November, pp. 1179-1205. 
http://dx.doi.org/10.1002/smj.705

Christiansen Poul Erik, Maltz, Arnold (2002) Becoming an 'Interesting' Customer: Procurement Strategies for Buyers Without Leverage, in International Journal of Logistics: Research and Applications, vol. 5, n. 2, pp. 177-195.

http://dx.doi.org/10.1080/13675560210148678

Colovic Ana (2007) Attractiveness of Territories for the Localisation of R\&D Activities: A Study of Determinant Factors, DRUID Summer Conference 2007 on Appropriability, Proximity, Routines and Innovation, Copenhagen, CBS, Denmark, June 18 - 20, 2007 (http://www2.druid.dk/conferences/viewpaper.php?id=1600\&cf=9)

Corniani Margherita (2010) The Cost of Managing Intangibles in Global Markets, Symphonya. Emerging Issues in Management (symphonya.unimib.it), n. 2, pp. 52-66.

http://dx.doi.org/10.4468/2010.2.05corniani

de Hoghton C. (1966) Cross-Channel Collaboration: A Study of Agreements Between British and Continental Firms, P.E.P, London.

Deligonul Seyda, Elg Ulf, Cavusgil Erin, Ghauri Pervez N. (2013) Developing strategic supplier networks: An institutional perspective, in Journal of Business Research, vol. 66, pp. 506-515.

http://dx.doi.org/10.1016/j.jbusres.2011.12.003

Dicken Peter, Malmberg Anders (2001) Firms in Territories: A Relational Perspective, in Economic Geography, vol. 77, n. 4, pp. 345-363.

http://dx.doi.org/10.1111/j.1944-8287.2001.tb00169.x

Dyer Jeffrey H., Singh Harbir (1998) The Relational View: Cooperative Strategy and Sources of Interorganizational Competitive Advantage, in The Academy of Management Review, vol. 23, n. 4, pp. 660-

http://dx.doi.org/10.5465/AMR.1998.1255632679

Day Marc, Fawcett Stanley E., Fawcett Amydee M., Magnan Gregory M. (2013) Trust and relational embeddedness: Exploring a paradox of trust pattern development in key supplier relationships, Industrial Marketing Management, vol. 42, n. 2, pp. 152-165.

http://dx.doi.org/10.1016/j.indmarman.2012.12.004

Dicken Peter, Malmberg Anders (2001) Firms in Territories: A Relational Perspective, Economic Geography, vol. 77, n. 4, pp. 345-362.

http://dx.doi.org/10.1111/j.1944-8287.2001.tb00169.x

DiMaggio Paul J., Powell Walter W. (1983) The Iron Cage Revisited: Institutional Isomorphism and Collective Rationality in Organizational Fields, American Sociological Review, vol. 48, n. 2, pp. 147-160.

Dyer Jeffrey H., Nobeoka Kentaro (2000) Creating and Managing a High-Performance Knowledge Sharing Network: The Toyota Case, in Strategic Management Journal, vol. 21, n. 3, pp. 345-367.

http://dx.doi.org/10.1002/(SICI)1097-0266(200003)21:3<345::AID-SMJ96>3.0.CO;2-N

Elg Ulf, Deligonul Seyda Z., Ghauri Pervenez N., Danis Wade, Tarnovskaya Veronika (2012) Market-Driving Strategy Implementation through Global Supplier Relationships, Industrial Marketing Management, vol. 41, n. 6, pp. 919-928.

http://dx.doi.org/10.1016/j.indmarman.2011.11.001

Farrell Diana (2005) Offshoring: Value Creation through Economic Change, Journal of Management Studies, vol. 42, n. 3, pp. 675-683.

http://dx.doi.org/10.1111/j.1467-6486.2005.00513.x

Gattai Valeria, Molteni Corrado (2007) Dissipation of Knowledge and the Boundaries of the Multinational Enterprise, Review of World Economics, vol. 147, pp. 1-26.

http://dx.doi.org/10.1007/s10290-007-0096-x

Geringer J. Michael (1991) Strategic Determinants of Partner Selection Criteria in International Joint Ventures, Journal of International Business Studies, vol. 22, n. 1, pp. 41-62.

http://dx.doi.org/10.1057/palgrave.jibs.8490291 
Glaister Keith W. (1996) Theoretical Perspectives on Strategic Alliances Formation, in P.E. Earl (ed.), Management, Marketing, and the Competitive Process, Edward Elgar, Cheltenham, Chapter 4, pp. 78-111.

Glaister Keith W., Buckley Peter J. (1996) Strategic Motives for International Alliance Formation, Journal of Management Studies, vol. 33, n. 3, pp. 301-332.

http://dx.doi.org/10.1111/j.1467-6486.1996.tb00804.x

Grant Robert M. (1996) Toward a Knowledge-Based Theory of the Firm, Strategic Management Journal, vol. 17, pp. 109-122.

http://dx.doi.org/ 10.1002/smj.4250171110

Gulati Ranjay (1995) Social Structure and Alliance Formation Patterns: A Longitudinal Analysis, Administrative Science Quarterly, vol. 40, pp. 619-652.

http://dx.doi.org/ 10.2307/2393756

Ivens Björn Sven, van de Vijver Mark, Vos Bart (2013) Managing and Developing Key Supplier Relationships: An Introduction to the Special Issue, Discussion and Implications, Industrial Marketing Management, vol. 42, pp. 135-138.

http://dx.doi.org/10.1016/j.indmarman.2013.01.002

Ellegaard, Chris, Johansen John, Drejer Anders (2003) Managing Industrial Buyer-Supplier Relations. The Case for Attractiveness, in Integrated Manufacturing Systems, vol. 14, n. 4, 346356.

http://dx.doi.org/10.1108/09576060310469725

Hamel Gary (1991) Competition for Competence and Inter-Partner Learning with International Strategic Alliances, Strategic Management Journal, vol. 12, pp. 83-103.

http://dx.doi.org/10.1002/smj.4250120908

Harrigan Kathryn Rudie (1988) Joint Ventures and Competitive Strategy, Strategic Management Journal, vol. 9, pp. 141-158.

http://dx.doi.org/10.1002/smj.4250090205

Harzing, Ann-Wil (2002) Acquisitions versus Greenfield Investments: International Strategy and Management of Entry Modes, Strategic Management Journal, vol. 23, pp. 211-227.

http://dx.doi.org/10.1002/smj.218

Hennart Jean-François (1991) Control in Multinational Firms: The Role of Price and Hierarchy, Management International Review, vol. 31, 71-97.

Hill Hal (1990) Foreign Investment and East Asian Economic Development, Asian-Pacific Economic Literature, vol. 4, n. 2, pp. 21-58. http://dx.doi.org/10.1111/j.1467-8411.1990.tb00176.x

Hitt Michael A., Dacin M. Tina, Levitas Edward, Arregle Jean-Luc, Borza Anca (2000) Partner Selection in Emerging and Developed Market Contexts. Resource Based and Organizational Learning Perspectives, Academy of Management Journal, vol. 43, n. 3, pp. 449-467. http://dx.doi.org/10.2307/1556404

Holmen Elsebeth, Aune Tina B., Pedersen Ann-Charlott (2013) Network Pictures for Managing Key Supplier Relationships, Industrial Marketing Management, vol. 42, pp. 139-151.

http://dx.doi.org/10.1016/j.indmarman.2012.12.003

Hultman Jens, Johnsen Thomas, Johnsen Rhona, Hertz Susanne (2012) An Interaction Approach to Global Sourcing: a Case Study of IKEA, Journal of purchasing and supply management, vol. 18, n. 1, pp. 9-21.

http://dx.doi.org/10.1016/j.pursup.2011.11.001

Kotabe Masaaki, Murray Janet Y., Mol Michael J. (2008) Global Sourcing Strategy and Performance. A "Fit" Versus "Balance" Perspective, in Jean J. Boddewy (ed.), International Business Scholarship: AIB Fellows on the First 50 Years and Beyond, Jai Press, Emerald, Bingley, vol. 14, pp. 259-277.

http://dx.doi.org/10.1016/S1064-4857(08)00008-9 
Lavie, Dovev (2006) The Competitive Advantage of Interconnected Firms: An Extension of the Resource-Based View, in Academy of Management Review, vol. 31, n. 3, pp. 638-658.

http://dx.doi.org/10.5465/AMR.2006.21318922

Lewin Arie Y., Volberda Henk W. (2011) Co-evolution of Global Sourcing: The Need to Understand the Underlying Mechanisms of Firm-Decisions to Offshore, in International Business Review, vol. 20, pp. 242-251.

http://dx.doi.org/10.1016/j.ibusrev.2011.02.008

Li Jing, Li Yong (2010) Flexibility versus Commitment: MNEs' Ownership Strategy in China, in Journal of International Business Studies, vol. 41, n. 9, pp. 1550-1571.

http://dx.doi.org/10.1057/jibs.2010.25

Li Jiatao, Xie Zhenzhen (2011) Global R\&D Strategies in an Emerging Economy: The Development and Protection of Technological Competencies, European Management Review, vol. 8, pp. 153164.

http://dx.doi.org/10.1111/j.1740-4762.2011.01013.x

Lin Xiaohua (2010) State versus Private MNCs from China: Initial Conceptualizations, in International Marketing Review, vol. 27, n. 3, pp. 366-380.

http://dx.doi.org/10.1108/02651331011048023

Manning Stephan, Lewin Arie Y., Schuerch Marc (2011) The Stability of Offshore Outsourcing Relationships: The Role of Relation Specificity and Client Control, Management International Review, vol. 51, pp. 381-406.

Martinez-Noya Andrea, Garcia-Canal Esteban, Guillen Mauro F. (2013) R\&D Outsourcing and the Effectiveness of Intangible Investments: Is Proprietary Core Knowledge Walking Out the Door?, Journal of Management Studies, vol. 50, n. 1, pp. 67-91.

http://dx.doi.org/10.1111/j.1467-6486.2012.01086.x

Makkonen Hannu, Olkkonen Rami (2013) The Conceptual Land Functionality of Key Supplier Management: A Multi-Dyadic Qualitative Study, Industrial Marketing Management, vol. 42, pp. 189-201.

http://dx.doi.org/10.1016/j.indmarman.2012.12.007

Meyer John W., Rowan Brian (1977) Institutionalized Organizations: Formal Structure as Myth and Ceremony, American Journal of Sociology, vol. 83, n. 2, pp. 340-363.

Minagawa Tetsuya Jr., Trott Paul, Hoecht Andreas (2007) Counterfeit, Imitation, Reverse Engineering and Learning: Reflection from Chinese Manufacturing Firms, $R \& D$ Management, vol 37, n. 5, pp. 455-467. http://dx.doi.org/10.1111/j.1467-9310.2007.00488.x

Mol Michael J., Brewster Chris (2013) The Outsourcing Strategy of Local and Multinational Firms : a Supply Base Perspective, in Global Strategy Journal, In Press.

Moore Christopher M., Doherty Anne Marie, Doyle Stephen A., Flagship Stores as a Market Entry Method: the Perspective of Luxury Fashion Retailing, in European Journal of Marketing, vol. 44, n. 1-2, pp. 139-161.

http://dx.doi.org/10.1108/03090561011008646

Morschett Disk, Schramm-Klein Hanna, Swoboda Bernanrd (2010) Decades of Research on Market Entry Modes: What do We Really Know About External Antecedents of Entry Mode Choice?, in Journal of International Management, vol. 16, n. 1, pp. 60-77.

http://dx.doi.org/10.1016/j.intman.2009.09.002

Murray Janet Y., (2001) Strategic Alliance-Based Global Sourcing Strategy for Competitive Advantage: A Conceptual Framework and Research Propositions, in Journal of International Marketing, vol. 9, n. 4, pp. 30-58.

http://dx.doi.org/10.1509/jimk.9.4.30.19938 
Nagati Haithem, Rebolledo Claudia (2013) Supplier development efforts: The suppliers' point of view, Industrial Marketing Management, vol. 42, n. 2, pp. 180-188.

http://dx.doi.org/10.1016/j.indmarman.2012.12.006

Nielsen Bo Bernhard (2002) How Do Firms Select their Partner for International Strategic Alliances? An empirical Investigation of the Drivers of International Strategic Alliance Formation, WP 5, Copenhagen Business School, Department of International Economics and Management, (http://openarchive.cbs.dk/bitstream/handle/10398/6539/bn-how20do20firms.pdf?sequence=1)

Nohria Nitin, Robert G. Eccles, Face to Face: Making Network Organizations Work, in N. Nohria, R.G. Eccles (eds.) (1992) Networks and Organizations: Structure, Form and Action, Harvard Business School Press, Cambridge, MA.

Overby, Mikkel Lucas (2005) Partner Selection Criteria in Strategic Alliances: When to Ally With Weak Partners, Danish Research Unit for Industrial Dynamics, Working Paper n. 05-07.

Peng, George Z. (2012) FDI Legitimacy and MNC Subsidiary Control: From Legitimation to Competition, Journal of International Management, vol.18, n. 2, pp. 115-131.

http://dx.doi.org/10.1016/j.intman.2011.12.001

Pfeffer Jeffrey, Nowak Phillip (1976) Joint Ventures and Interorganizational Interdependence, Administrative Science Quarterly, vol. 21, n. 3, pp. 398-418.

Porter Michael. E., Fuller Mark B. (1986) Coalitions and Global Strategy, in M.E. Porter (ed.), Competition in Global Industries, Harvard Business School, Boston, pp. 315-344.

Reus Taco H., Ritchie William J. III (2004) Interpartner, Parent, and Environmental Factors Influencing the Operation of International Joint Ventures: 15 Years of Research, Management International Review, vol. 44, n. 4, pp. 369-396.

Reynolds John I. (1979) India-American Joint Ventures: Business Policies Relationships, University Press of America, Washington D.C.

Roseira Catarina, Brito Carlos, Ford David (2013) Network Pictures and Supplier Management: An Empirical Study, Industrial Marketing Management, vol. 42, pp. 234-247.

http://dx.doi.org/10.1016/j.indmarman.2012.08.006

Sarkar M.B., Echambadi Raj, Harrison Jeffrey S. (2001) Alliance Entrepreneurship and Firm Market Performance, Strategic Management Journal, vol. 22, n. 6/7, pp. 701-711.

http://dx.doi.org/10.1002/smj.179

Sciarelli Mauro (2008) Resource-Based Theory and Market-Driven Management, Symphonya. Emerging Issues in Management (symphonya.unimib.it), n. 2, 2008, pp. 66-80.

http://dx.doi.org/10.4468/2008.2.06sciarelli

Selin Soner Kara, Ayadi Omar, Cheikhrouhou Naoufel (2012) An Extensive Group Decision Methodology for Alliance Partner Selection Problem in Collaborative Networked Organisations, in International Journal of Applied Logistics (IJAL), vol. 3, n. 1, pp. 1-19.

http://dx.doi.org/10.4018/jal.2012010101

Steinle Claus, Schiele Holger (2008) Limits to Global Sourcing? Strategic Consequences of Dependency on International Suppliers: Cluster Theory, Resource-Based View and Case Studies, in Journal of Purchasing and Supply Management, vol. 14, n. 1, pp. 3-14.

http://dx.doi.org/10.1016/j.pursup.2008.01.001

Trott Paul, Hoecht Andreas (2007) Product Counterfeiting, Non-Consensual Acquisition of Technology and New Product Development: An Innovation Perspective, European Journal of Innovation Management, vol. 10, n. 1, pp. 126-143.

http://dx.doi.org/10.1108/14601060710720582

Varis Jary, Conn Steffen (2002) Alliance Partner Selection. A Literature Review, WP 14 Telecom Business Research Center Lappeenranta, Finland.

Yan Aimin, Luo Yadong (2001) International Joint Ventures: Theory and Practice, M.E. Sharpe Inc., New York.

Yang Deli (2012) Arm's Length and Captive Transactions: Patent-Based View of Control in Internationalization, International Business Review, vol. 21, n. 4, pp. 575-588.

http://dx.doi.org/10.1016/j.ibusrev.2011.07.004 
Wen Sonya H., Chuang Cheng-Min (2010) To Teach or to Compete? A Strategic Dilemma of Knowledge Owners in International Alliances, Asia Pacific Journal of Management, vol. 27, n. 4, pp. 697-726.

http://dx.doi.org/10.1007/s10490-008-9127-y

Williamson Oliver E. (1985)The Economic Institutions of Capitalism: Firms, Markets, Relational Contracting, Free Press, New York. 